1

\title{
Alvin W. Gouldner and the Tragic Vision IN Sociology*
}

\author{
JAMES J. CHRISS \\ Cleveland State University
}

Social Thought \& Research, 2000, Vol. 23, 1\&2

Abstract

\begin{abstract}
Alvin Gouldner's life and work is considered within the framework of bis own attempt to fashion a reflexive sociology during the second balf of bis career. In the first balf, Gouldner was a functionalist and dutifully contributed insights and theoretical innovations to the paradigm, even while remaining critical of Talcott Parsons' own version of structural-functionalism. Later, by 1962, Gouldner broke from the dominant tradition to become an outspoken critique of establishment sociology, in the process becoming more sympathetic to competing theories, especially Marxism. Eventually, Marxism, too, was found to be inadequate because of its lack of reflexivity, and Gouldner became further alienated from both traditions of sociology. Concomitantly, Gouldner was battling on personal and professional fronts in bis role of social critic. He became increasingly bostile toward others for their willing compliance with prevailing cultural prescriptions, which be believed were robbing human beings of their agency, vitality, and will to power. Lacking authentic knowledge of oneself, one could not bope to create social theories which benefited society and con-
\end{abstract}

* An earlier version of this paper was presented to the University of Kansas sociology department as a talk entitled "What Can We Learn From Gouldner?" on October 22, 1998. I especially want to thank Dan Krier, Mark Worrell, Robert Antonio and David Smith for providing feedback and helpful comments. A fuller account of Gouldner's life and work can be found in Chriss (1999a). Comments to the author should be sent to James J. Chriss, Cleveland State University, Department of Sociology, Cleveland, Oh 44115. e-mail: j.chriss@csuohio.edu 
tributed to the liberation of the buman spirit. Gouldner was a tragic bero, for although be came to an understanding of the limitations of buman strivings in creating socially beneficial social theory, and fought valiantly to establish a program to fill this lacuna, be ultimately failed to deliver upon the promise of these insights because of bis own bubris (on the personal front) and the internal paradoxes of reflexive sociology (on the professional front).

\section{Learning from Gouldner}

When we talk about what we can "learn" from a particular person's ideas, we need to go about the business of defining more precisely what sorts of things we want to learn, and for what purpose(s). These questions are of course intimately connected to the particular interests of the audience to whom one is conveying such information. I presume that since the core audience of interest here is sociologists and social scientists more generally, whatever is of abiding interest in Gouldner's thought must somehow be shown to be of relevance to the sorts of issues and questions sociologists are confronting and asking today.

But the business of identifying the central issues or topics of abiding interest to contemporary sociologists is not as easy or straightforward as it might appear. The conundrum is that sociology is a broad discipline encompassing virtually the entire spectrum of conceivable social phenomena. Just about anything occurring in the social world has, or soon will be, treated in some way or another by sociologists. Many years ago Gouldner (1956, 1957, $1962,1976 \mathrm{~b})$ himself tried to downplay the too easy distinctions some of us make regarding what are or are not worthy topics of sociological theory and research. The old "pure" versus "applied" knowledge debate always lurks just around the corner whenever one attempts to go about the business of identifying topics of "relevance" to a scholarly audience.
As much as anything, Gouldner's legacy to sociology can be understood as a call to sociologists to be wary of the extracognitive factors influencing the types of research agendas we pursue and the allegiances we develop-to other colleagues, to funding agencies, to institutions-along the way (see especially Gouldner 1968, $1969,1975)$. Here is where the Gouldnerian legacy becomes a source of frustration for those of us who simply want to get on with the business of explaining, predicting, and describing aspects of the social world. That is, Kuhn (1970) once stated that traditional science works best when it has its blinders on. The 1940s and 50s were an especially good time for sociology in terms of its growing legitimacy in the eyes of the academy, the state, and society more generally. Of course in the 1960 s sociology reached a peak in terms of number of sociology undergraduate majors and number of persons writing sociology master's theses and dissertations (see Turner and Turner 1990). But it was also a period of increasing criticism of the discipline from within, and Gouldner (1970) was certainly a central player contributing to these criticisms of academic or establishment sociology. Among other things, this increasing criticism reflected a greater disciplinary self-awareness as sociology became established and began to take for granted the utility, efficaciousness, and desirability of its theories, interests, and knowledge claims.

If we were to single out one person who could be said to have presided over the growth of sociology during this period, it would have to be Talcott Parsons. Parsons' entire career was devoted to trying to bring sociology to the table of science, a legacy brilliantly summarized in Klausner and Lidz's Nationalization of the Social Sciences (1986). Parsons believed that the force of reason"cognitive rationality," as he called it-once channeled appropriately along the lines of positivistic science, would indeed lead us to uncovering the timeless laws of the social universe, thereby eventually fulfilling Comte's utopian vision of a social world characterized by social justice and the elimination of misery and oppression. 
Why then did Gouldner become such a vocal critic of Parsons beginning in the 1950s and extending on until his own death in 1980? When Parsons died in 1979, Gouldner offered this moving and heartfelt remembrance of Parsons:

Talcott Parsons was a very special man and played a very special role. It is a mark of his achievement that most of us who became sociologists after World War II felt constrained to define our own intellectual position in relation to his own work. We also noted the very special way he walked through the world. Although a thinker of great stature, he was a diffident, tentative, indeed humble man, accessible to young people whom he did not know, and quite approachable by all at public meetings... I knew him as a thoughtful and kind man who, despite a legion of responsibilities, still found time to chat with visitors at Harvard. He never forgot to fill his guests' glasses. I remember him, too, at the meetings of the American Sociological Society in St. Louis in 1961, steadfastly and successfully resisting efforts to im-pose a racially discriminatory use of hotel facilities upon our convention. Unlike some intellectuals, who demand great personal license in exchange for their brilliance, he moved quietly among us trying to be a good man rather than pretending to be a god.' (Gouldner 1979b, pp. 300301)

Gouldner was in rare form here. He generally was not quite so gracious and accommodating in his comments about others. Indeed, legends about Gouldner's belligerent interpersonal style and impatience with others, be they colleagues, students, or others abound. He was a powder keg ready to explode. At timesoften-he was an angry, hostile, and vindictive man.

Yet Gouldner the scholar was quite an acceptable, and indeed welcome sight for many. Although he had a confrontational and aggressive teaching style, most every student of Gouldner's with whom I have spoken suggest that they learned a lot from him, and were challenged to develop deeper and more sophisticated skills of observation, analysis, and interpretation. Among the things we can learn from Gouldner, then, is how he negoti- ated the dichotomies that marked him as both a man and as a scholar. The bifurcated nature of Gouldner's work and life is captured in his penchant for playing the insider/outlaw game.

\section{The Insider/Outlaw Game}

Whether by design or for some other reason (the unfolding of the Geist, unconscious motivation, the structure of higher education, imitation) Gouldner played the role of insider/outlaw consistently throughout his career. Early on, during his days at Columbia University studying under Merton and then on to a successful career as an industrial sociologist during the 1950s and early 60 s, Gouldner was a functionalist and consummate insider to establishment sociology. Granted, his version of functionalism was in opposition to the Parsonian variety, seeing as how Merton was attempting to establish his own brand of functionalism based upon middle-range propositions, the case method, and the introduction of concepts such as latent and manifest function, as well as dysfunctions. Gouldner was trained by Merton to maintain a critical eye toward received wisdom, and to not accept it merely on the basis of its wide acceptance or the perceived moral authority, competence, or brilliance of its author or authors.

Although Gouldner was critical of Parsons from early in his career, his aim, at least initially, was not to cripple or eradicate functionalism, but to rehabilitate it by overcoming the weaknesses of the establishment version of functionalism, especially with regard to its tendency toward illegitimate teleology (system "needs") and the conservative implications of its (Parsons') "obsession" with value consensus as the basis of social order.

For example, in his 1960 article "The Norm of Reciprocity" (still his single-most heavily cited paper), the lacuna that Gouldner raised to conscious awareness and then attempted to fill was that, although many authors had previously dealt with the issue of 
reciprocity in social relations, no one had gone to the trouble of defining the term explicitly. This failure to define reciprocity reflected a taken-for-grantedness on the part of social theorists about its unquestioned importance in contributing to stable social relations. As such, reciprocity tended to enter through the backdoor, always lying at the heart of social explanation, but rarely avowed or even noticed by theorists themselves. The assumptions concerning reciprocity reside, then, at a tacit subtextual (infrastructural) level of functionalist theory, and Gouldner was concerned with analyzing the implications for functionalism once their importance is recognized and overtly acknowledged.

One such implication is connected with functionalism's glossing over the possibility that the power differentials between Ego and Alter (or between any units in the social system) may be large. In this case, Ego may force Alter to benefit it with little or no reciprocity. Although on the surface stable social relations could appear to be maintained even with such power disparities, the "stable" social system that functionalists portray is not quite what it appears to be. In fact, functionalism's silence on the possibility of power differentials and coercion as the basis of social order (rather than consensus) represents a critical theory that could be cracked open from functionalism if only theorists such as Parsons were self-reflexive enough to understand the implications of their tacit assumptions about reciprocity. As Gouldner (1960) states, "In any event, the present analysis of reciprocity opens up long-neglected questions, yielding a new perspective on the relation between functional theory and the concepts of 'survival' and 'exploitation.' In the latter case, moreover, intimations emerge of some of the ways in which two diverse theoretical traditions contain surprising convergences" (p. 167). This idea of a convergence between functionalism and Marxism would in fact become one of the major elements of Gouldner's (1970) "coming crisis" thesis.
Gouldner's penchant for analyzing extant theory and cracking open its unstated assumptions - a program of inquiry which Gouldner would develop explicitly in the guise of reflexive sociology-derives, as we have seen, from the training he received from Merton at Columbia University. Gouldner felt this was a viable way of contributing to the development of sociological theory, insofar as the program was aimed at solving some of the persistent problems of functionalist theory, rather than working to overthrow it entirely. Because Parsonian structural functionalism was dominant during this time, the $50 \mathrm{~s}$ and early $60 \mathrm{~s}$-in an earlier paper I (Chriss 1995b) calculated that Parsons' influence peaked in 1963-Gouldner's paper on reciprocity was written in a tolerant, scholarly tone that, while critical, nevertheless reflected his continuing-but by this time waning-immersion in what he would later deride as "establishment" sociology. Indeed, at this time Gouldner still clung to a positivistic world view, reflected for example in his view of science: "The task of the sociologist, in this regard, parallels that of the physicist who seeks to identify the basic particles of matter, the conditions under which they vary, and their relations to one another" (Gouldner 1960 , p. 171). This should immediately be contrasted with the position Gouldner was taking a decade later, where he was becoming more sympathetic to hermeneutics, this being a method in which "the theorist is regarded as being more like an art or architectural critic than a physicist" (Gouldner 1972, p. 15). This represents quite a radical transition from a physicalist to a symbolist frame of reference.

Gouldner's unique perspective on the silent role of reciprocity in functionalist theory led him to ask questions that other functionalists rarely asked themselves. Although functionalists had dealt with the positive functions of reciprocity, namely, its stabilizing function for the broader social system, Gouldner notes that, because functionalists have rarely been concerned with etiology, they have thereby neglected the possibility that reciprocity is not only a stabilizing mechanism but also a "starting mecha- 
nism." That is, the norm of reciprocity not only stabilizes social relationships, but may also be functional in the early stages of development of a social system and the institutionalization of role relationships, before a customary set of such status duties have been established.

In this case, according to Gouldner, "we find ourselves outside the usual perspective of functional theory" (Gouldner 1960, p. 176). In fact, functionalism's interest in already established social systems, to the neglect of their social origins, reflects a decidedly presentist bias which opens up functionalism (and especially Parsons) to the charges of conservatism and that it is merely a defender of the status quo. Still, Gouldner is not suggesting that functionalism cannot accommodate historical or hermeneutic methods. Although it at first may appear alien to functionalists, the consideration of reciprocity as a starting mechanism is possible and wholly within the scope of functionalist theory, according to Gouldner, if only functionalists were more overt and diligent in analyzing and reflecting upon their own tacit assumptions about the world (Gouldner 1960, p. 177).

All the while that Gouldner was playing the game of insider to establishment sociology, however, he was preparing for a metamorphosis into an outlaw functionalist/Marxist insider. Gouldner was born in Harlem in 1920, and was part of the large wave of sons and daughters of the second and third generations of Jewish immigrants who had come to America beginning in the 1880s. He attended City College of New York, and graduated with a BBA in 1941. City College was a feeder to Columbia University and other prestigious institutions of higher learning, and by the time Gouldner had arrived at Columbia in 1943, he had already developed radical political sensibilities (which was somewhat of an oddity considering he was coming out of the business school). Gouldner was in fact a Stalinist in his early days, and was a member of several socialist organizations during the 1940s (Miller 1981; Page 1982.) Yet in his dissertation, parts of which eventually wound up as his first two books, Patterns of Industrial Bureaucracy (1954a) and Wildcat Strike (1954b), Gouldner rarely even mentioned Marx, choosing instead the "safer" critical theory of Max Weber. (This also made sense since Weber had put organizational analysis on the map with his theory of bureaucracy.)

Why was Marx absent from Gouldner's early work? Some (Burawoy 1982; Stein 1982) suggest that, as his books were coming to press in the 1950s, the specter of Joseph McCarthy hung over the heads of many scholars with Marxist or socialist sympathies, and he opted for a pragmatic solution to his dilemma. Regardless, by the 1960s Gouldner had almost completely forsaken academic or establishment sociology in favor of critical theory of the Marxist variety.

Gouldner would eventually go on to publish many critical, even strident renunciations of Parsons and academic sociology (the most well-known being of course The Coming Crisis of Western Sociology) while turning his attentions more and more to Marxism, intellectuals and their culture of critical discourse, and ideology and technology. Gouldner would eventually find fault with Marxism as well, because it too was insufficiently self-reflexive, e.g., Marx's theory of the proletarian revolt cannot account for how Marx, from a bourgeois background, came to acquire a proletarian consciousness. It appears to refute his theory that the material conditions of existence that persons experience in their everyday lives account for the ideas they come to hold about the world (Gouldner 1980). Gouldner thus makes another transformation from Marxist insider to Marxist outlaw. He had seen, and experienced as a lived conviction, the dark side of the dialectic. Rather than pursuing this issue further, let us turn to 1965, with the publication of Enter Plato, his study of the social origins of social theory and the transitions in thought that took place from Socrates to Plato. 


\section{Enter Plato}

In many ways Enter Plato mirrors Gouldner's own life. Gouldner clearly has great respect and admiration for ancient Greek society, its men, and its ideas. For example, Gouldner lauds the Greek's shame culture-where what's considered important are the perceptions and opinions of others rather than one's own thoughts or self-assessments-as opposed to that which characterizes modern society-namely a guilt culture, whereby people turn inward onto their own thought and feelings, thereby giving rise to unhealthy trends such as egoistic individualism. Because others' opinions of you count so much, the Greeks developed the contest system that acted as a mechanism for overtly assessing the ways in which selves are being viewed in the eyes of the broader society. The contest system in essence, then, serves to objectivity the shame culture.

Obviously, the contest system can lead to distortions in interpersonal relations, as people might be prone to act strategically in their own interests with regard to guarding or maintaining their own status or position in society at the expense of others. Because of the intense competition arising out of a shame culture, the Greeks were concerned, indeed obsessed with the imperfections of human beings and society, realizing that one of our (their) greatest tragedies is that we all suffer from vanity, pride, and a deep sense of hubris - that is, insolence, wanton violence, and outrage. This mortal flaw was a constant threat to reasoned and collegial discourse between men and women, as Plato suggested. Indeed, Gouldner championed the idea of the Greek dialectic, characterized as a reasoned search for the truth where ideas are exchanged and claims are made amongst a group of colleagues. The problem with this ideal speech situation, if I may borrow a phrase from Habermas $(1984,1987)$, is that it always runs the risk of breaking down into undesirable forms of exchange where people engage in innuendo, ad hominem attacks, and defensiveness. This form of distorted communication is la- beled eristic, that is, communication that is characterized as captious and full of strife, quarrels, and wrangling. Rather than seeking the truth through reasoned dialogue, persons engaging in eristic discourse seek to humiliate and destroy the other.

Without being too melodramatic, I would suggest that Gouldner identified with Greek culture to such an extent, and adopted Plato's desperate attempt to fashion the just society as his own, because his own life was similar to a Greek tragedy. In many ways Gouldner was a protagonist in a Greek drama, and this played out both in his professional and private lives. Through the role he played as academic insider/outlaw, and through the life he led as a "difficult" person who violated the sensibilities of many he came into contact with because of his own personal hubris, Gouldner felt a kinship with the despair and fatalism that the ancient Greeks felt whenever they faced their own limitations and failings as human beings.

Gouldner links his study of ancient Greek philosophy to contemporary social theory by suggesting that the history of social theory is an intellectual genre comprised of at least three partshistory, sociology, and criticism-and that the most important role the historian of social theory plays is that of critic. The role of critic, at least within the context of modern social science with its emphasis on quantitative methods and the assumption of valuefree knowledge, has become largely inimical to the goal of building a cumulative science that sees little utility in visiting and reflecting back upon great intellectual predecessors. That is, according to the tenets of positivism and the cumulative nature of scientific knowledge, whatever is useful in the thought of earlier generations of thinkers has presumably been absorbed into current disciplinary canons. Hence the history per se of theorists is rendered at best an academic exercise reserved largely for graduate students, while at worst, a waste of time representing the height of intellectual solipsism and disciplinary navel-gazing. 
The critic finds him-or herself caught up in the tension between affirming the creative potential of the individual (insofar as the critic bucks the trend toward disciplinary parochialism), and opposing the demands of conformity to established institutions and culturally standardized roles (Gouldner 1965, p. 170). The critic hates routinization of his or her professional role; derives little pleasure from the traditional rewards the university confers upon him or her (for example, good student evaluations or peer reviews, or the occasional merit-based promotion along the tenure track); resists compromising his or her beliefs for the sake of political expediency; cares more for the creativity of a scholarly performance rather than its reliability or utility. In sum, the critic detests the domestication of intellectual life in whatever form it takes.

Indeed, this is what Gouldner describes as the "tragic" dimension in science, especially as this pertains to the reflexive and critical social theorist. As Gouldner (1975-76, p. 23) states, "To be a practitioner of 'critique' means in part to employ a standpoint outside of a normal science and its established paradigms." Again, returning to a sentiment from Kuhn, adapting the role of social critic removes the blinders that make normal science motivating and possible (Nord 1992, p. 353).

The critic, then, must always be aware of the disjunction between his own profession and himself, and must struggle ceaselessly against surrendering herself to routine and the cozy "perks" of intellectual life (whatever there really are of them). Gouldner (1965) states:

The historical mission of the social theorist is to assist mankind in taking possession of society. The task of the historian of theory is to assist us in taking possession of our own intellectual heritage, past or present, by appraising it actively-which is to say, critically-in terms of our viable interests. (p. 170)
Being a critic also means being aware of one's tacit (domain) assumptions about the world. Only through such a program of self-reflexivity, whereby theorists make an overt connection between the technical level of theory and its infrastructure (assumptions about epistemology, ontology, and axiology), can theorists hope to produce theories that maintain fidelity with the empirical social world. But if indeed social theorists are to embrace the role of critic, as Gouldner espouses, how far can or should this critical, self-reflexive method be taken? Isn't it likely the case that somewhere along the way such a self-reflexive program of critical theory will reach a point of diminishing return? Can a line easily be drawn between criticism for the sake of clarifying one's philosophical commitments, on the one hand, and criticism merely for the sake of criticism, on the other? Also, doesn't such a strong emphasis on self-reflexivity defeat the hopes or aspiration of an other-directed, shame culture characterized by reasoned discourse as embodied in the Greek dialectic?

Gouldner seemed to have arrived at the horns of this dilemma near the end of his life, and was leaning toward the position that indeed the program of self-reflexivity becomes a "runaway norm" which, by collapsing back upon itself and bringing into doubt the very foundations of its own assumptions and cognitive framework through endless cycles of self-critique, ultimately disestablishes everything in its path, including itself.

This appears to be the tragic fate of the critical social theorist, and signals the dead-end of Gouldner's version of reflexive sociology. Alvin Gouldner's life and work reflected this eternal struggle with the internal contradictions of legitimate knowledge, and how to maintain critical insights into that knowledge rather than accepting it passively, the latter of which serving merely to reaffirm and accept the status quo. There have been many forms of oppression justified on the basis of the status quo, and Gouldner tried to create a program of inquiry that was alive and sensitive to this reality. 
One particular question that Gouldner struggled with, then, was: How does one simultaneously create legitimate knowledge that is both liberating and humane, but without going in the direction of radical or egoistic individualism (such as what has happened with the emphasis on "self-esteem" and "empowerment" that afflicts psychology, management, and the modern therapeutic state more generally [see Chriss 1999b]; or the faddish appropriation by educational institutions of the potentially liberative program of "critical thinking," especially the Freirean tradition)? With both academic sociology and Marxism failing to live up to the task because of their lack of reflexivity, Gouldner believed, for awhile anyway, that he had located the historical actor or class that could deliver such a program, namely, the New Class of intellectuals armed with their own unique language variant, the culture of critical discourse. But they too, described by Gouldner (1979a) as a "flawed universal class," failed to deliver the goods. In order to understood this tragic state of affairs, we need to return to Gouldner's writings on the link between personal reality and social theory.

\section{Gouldner's Personal Reality and Social Theory}

A theme we have already touched upon is Gouldner's "difficult" personality, and how this affected him in the role of intellectual and social critic. By Gouldner's own definition of intellectuals, technical intelligentsia, and the New Class, Gouldner himself was a member of this New Class of intellectuals. We have also seen evidence that Gouldner became alienated from both standard sociology and Marxism over his career, thus staying true, self-reflexively, to his general insight that the New Class is a flawed universal class.

Gouldner was notorious for having a volcanic temperament, for his interpersonal belligerence, and for his zealous-some would say overzealous-application of the Socratic Method in his classroom (even going so far as occasionally driving students to tears).
Indeed, Lewis Coser (1982) once said that "He [Gouldner] knew, as he once wrote to his lifelong friend Robert $\mathrm{K}$. Merton, that many people considered him a son of a bitch, and he half agreed with their assessment" (p. 888).

Intellectuals who commit themselves to a program of critical social theory tend to experience blocked ascendance, in terms of their progression through the ranks of education or government, because they may step on some well-heeled toes as they articulate the links between others' personal realities, economic interests, practices, and claims of professional expertise. As Gouldner (1979a) states, "The impairment of the New Class's upward mobility, either politically or economically, contributes to their alienation." Critical social theorists are also angry because some part of the world they cherish is in decline or disarray, and they hate the complacency of others for not attending to these pathological conditions or caring about the plight of the oppressed.

In taking the stance of the critic, genuinely reflexive social theorists seem to have no other choice but to wear their personal animus on their sleeve. To do otherwise would be to repress the inexorable link between personal realities and social theory, between private troubles and public issues (Mills 1959). Gouldner was throughout his career ambivalent at best, and oftentimes hostile towards, the world of mere appearances, as represented especially in Erving Goffman's (1959) dramaturgical theory of action (see, e.g., Gouldner 1965, 1970, 1975-76, 1976a; Young 1971). Gouldner hated other things as well of course, including "Stalinism, structural theories, bureaucracy, statism, vanguard parties and the sociological establishment" (Alt 1981, p. 198).

Goffman developed a theory of modernity which suggests that through an elaborate structure of interaction rituals-tact, diplomacy, norms of politeness, body glass, facework, partitioning of front and back stages, role distance-actors maintain civility, decorum, and working definitions of the situation. But from 
Gouldner's perspective, such games of deference and accommodation serve to mask the "true" feeling and perspectives of actors, thus creating the conditions for greater distortion of communication as well as the tacit affirmation of the status quo.

Gouldner's passion for speaking the truth, then, made him enemies among those whose livelihoods or professional interests were at stake were the truth to be told. As Aya (1982, p. 907) suggests, Gouldner even considered universities and other institutions that put a premium on civility and collegiality as inhibiting of self-reflexivity and truth-telling as authoritarian political regimes. Indeed, Gouldner (1973, p. 77) once wrote that "Professional courtesy stifles intellectual curiosity; the teeth of piety bite the tongue of truth." On this point, Gouldner would agree, then, with Habermas (1984) and Argyris and Schon (1974) that truth-telling is part and parcel to reasoned communication. Hence, politeness and other etiquette norms - the basis of Goffman's dramaturgy - are cast into the realm of the irrational since they can work to mask persons' truthful assessments of a situation (Chriss 1995a, p. 550).

\section{Gouldner as Tragic Hero}

How has it arisen in modern society that so much emphasis is being placed on the self, including heavy doses of self-revelation (or disclosure), self-presentation, and self-analysis (or reflexivity), and how does this turn toward the self relate to Gouldner and the tragic vision more generally? As we have seen, the Greeks held out the tragic hero as one who worked against all odds to make the world a better place, but who because of his or her own fallibility (pride, envy, blind hatred, wanton lust, hubris) failed the ultimate tests of truth, honor, bravery, or redemption. From the ancient Greek perspective, since the tragic hero ultimately cannot be redeemed because of the inherent limitations and fallibilities of the human condition, the only place to turn to are the gods.
The rise of Enlightenment rationalism and scientism ushered in a massive repudiation of god and religion, and in this new form of secular humanism it was human beings who would make their own destiny and who would perfect human society on their own terms. The modern tragic hero is different, then, than the one portrayed in earlier times. Nietzsche's (1956) writings embody the modernist loss of certitude about the meaning of life, indeed, the sheer senselessness, absurdity, and nihilism of a life that lacks gods and other ultimate values, where men and women retreat back into their "selves" in a desperate search for meaning and foundation (Featherstone 1995, pp. 61-62). ${ }^{2}$ Consider Charles Glicksberg's (1963, p. 69) apt characterization of the modern tragic hero:

\begin{abstract}
The tragic vision today thus culminates in a naked revela tion of self, without the affirmation of values that lie beyond the sphere of the natural. The absurd hero, who is absurd even when he rebels, struggles painfully but resolutely toward the goal of full disclosure. Nothing can deter him from this passionate commitment to the truth. This is the distinctive mark of his tragic consciousness: he forges ahead despite his knowledge that he can do nothing to alter his lot. ...If he feels "guilty," it is not because he has transgressed against the laws of God but because he has violated his inner self or failed to keep faith with his fellow man, all of whom are victims of death but privileged beings for that very reason.
\end{abstract}

I would suggest that the above description of the modern tragic hero fits Gouldner remarkable well. Gouldner dutifully worked within the functionalist perspective early in his career, and clung tenaciously to the physicalist framework of positivistic social science until 1962, the year in which a peculiar little book was published entitled Notes on Technology and the Moral Order (Gouldner and Peterson 1962). Gouldner had spent the previous summer immersed in an intense workshop on quantitative methods and the newest statistical techniques, including factor analysis. Through factor analysis, Gouldner and Peterson (1962) hoped to settle once and for all a persistent problem of func- 
tional analysis, specifically, its circular reasoning insofar as the social system was typically conceptualized as a system of interdependent parts in which all parts and subsysterns affected all the other parts and subsystems. In this way functionalism explained everything, thereby explaining nothing.

Factor analysis promised a way of holding constant certain variables in a system of multiple variables or factors, thereby allowing determination of the relative "loading" or influence of each variable of interest. Gouldner and Peterson used as their data the Human Relations Area Files, which contained information on 71 primitive or pre-industrial societies. The authors grouped the data into various factors, such as Factor $\mathrm{L}$, which was a measure of lineality; Factor SD, or sex dominance; Factor $\mathrm{T}$, or level of technology; and the remarkable Factor A, their measure of morality which they dubbed "norm-sending." The A in Factor A stood for Apollonianism, which Gouldner and Peterson appropriated directly from Nietzsche's (1956) study of tragedy and the genealogy of morals. ${ }^{3}$ Nietzsche had suggested that ancient Greek society and certain other societies of antiquity were characterized by a Dionysian complex emphasizing such things as the pleasures of the flesh, rapture and intoxication, a tragic view of the world, and the acceptance of the terrors and horrors of existence. In contrast, later more rationalized societies were labeled as Apollonian, whose primary characteristic was "impulse control." Some of the factors included in the Apollonian ideal type were "freedom from all extravagant urges"; the stressing of cognitive modes of experience; reason, knowledge, and science; and "know thyself." Gouldner and Peterson found that societies which scored high on Factor A also tended to score high on Factor T, technology.

Although Gouldner seemed to have arrived at a new level of sophistication regarding functional analysis and an improved ability to judge the relative importance of variables in contributing to certain features or structures of the social system (here, the link between technology and morality), he seemed also to realize the extraordinary irony and incongruity of calling upon Nietzsche to help order his quantitative data and provide corroboration for his thesis. As Gouldner and Peterson (1962, p. 32) state,

...we are unhappily aware that, at this point, we may lose some of our remaining readers. We may lose those who feel that tainted philosophers have no place in a pure social science, or those whose liberal views are offended by Nietzsche's seeming anti-Semitism, or those who simply cannot bear the presumably gross incongruity of juxtaposing philosophical poetry and statistical analysis.

Notes on Tecbnology and the Moral Order was indeed Gouldner's last, desperate attempt to make sociology meaningful within the framework of functionalism and orthodox sociology. Beginning in 1962 and extending through his engagement with Plato in 1965 and on through the early 1970s with his increasingly strident denunciations of functionalism and establishment sociology, Gouldner's writings were characterized by an existential angst which expressed despair within modern sociology (Pavlich 1995, p. 548). This despair is the embodiment of Weber's (1947) lament regarding the rise of technical-instrumental rationality and the fact that modern men and women were increasingly becoming trapped in an "iron cage" of bureaucracy and technocracy.

Gouldner's realization was that sociology's unreflective embrace of positivism and the tenet of objective knowledge makes sociologists less vital and potent as actors in the world because they subordinate their own human judgments, hunches, insights, and designs for action to a sterile Apollianism embodied in a set of doctrinaire slogans designating "good science." As Gouldner (1969, p. xxxvii) explains,

The sociological enterprise, like others, becomes edged with a tragic sense, I suspect, precisely because in confining work to the requirements of a demanding and unfulfillable paradigm [positivism], sociologists are not using themselves up 
in their work but are, indeed, sacrificing unexpressed parts of themselves-their playful impulses, their unverified hunches, and speculative imagination-in a wager that this sacrifice is "best for science."

Gouldner suggests that men and women surmount tragedy only when they "use themselves up fully," wherever they are, and in whatever situation they find themselves, even if this means ignoring certain prevailing cultural prescriptions and acting in innovative or even deviant ways. In order to do this, men and women must accept their own unique talents and ambitions as authentic, and "must not cleave compulsively to a culturally prescribed and historically transient definition of what they should be doing scientifically." That is, sociologists escape tragedy only when they recognize that they need not allow themselves to be assimilated to their cultural masks (Gouldner 1969, p. xxxvi). Again, we see here Gouldner railing against dramaturgical conformity and compliance, and against the inauthentic modern selves which positivistic social science forces people to claim for themselves (see also Gouldner 1976a, 1976b).

\section{Nightmare Reflexive Sociology?}

Gouldner's attempt to rectify his earlier misguided allegiance to establishment sociology led him on a perilous journey back, ironically enough, to the heart of establishment sociology. Gouldner embraced the role of social critic with a vengeance, and tenaciously battled sociologists-friends and foes alike-on a variety of fronts. By offering himself as a model of how real flesh-andblood sociologists might escape their tragic fate and make a difference in the world, Gouldner incurred the wrath of the sociological establishment and seriously damaged himself-both professionally and personally, in the process. In an excoriating review of Coming Crisis of Western Sociology, Leo Kaplan (1971, p. 66) effectively makes Gouldner out to be both martyr and tragic hero:
Meanwhile, the saintly Gouldner, alone in his pristine purity, feels disgust, and, fighting off the seven deadly sins that surround him on all sides, pursues relentlessly, dialectically, reflexively, critically, intellectually and self-consciously the holy grail: the grand synthesis of Marxism with academic sociology. ${ }^{4}$

As much as Gouldner tried in the last two decades of his life to establish a program of reflexive sociology and to find a balance between the competing claims and visions of society offered by functionalists and Marxists, neither of these efforts could be described as completely successful (see Colvard 1990; Flacks 1990; Fuhrman 1990; Hagan and Vaughan 1990; Johnson 1990; Levesque-Lopman 1990; Phillips 1988). Indeed, just as he lauded Parsons in 1979 for "using himself up" through his passionate, lifelong attempt to bring sociology to the table of legitimate science, Gouldner's own program, which fell far short of the substantive accomplishments of Parsons' program, nevertheless could be considered successful only to the extent that Gouldner too "used himself up" in his heroic struggle to show sociologists that a blind allegiance to positivism and the assumptions of objective knowledge were antithetical to fashioning a truly liberative sociology.

The mistake that Gouldner made, and which also illustrates a "nightmare" version of his reflexive sociology-see Gouldner's (1980, pp. 380-389) discussion of "nightmare Marxism" for background-was in assuming that one cannot properly know oneself, and by extension, cannot thereby develop theories that maintain fidelity to the empirical social world, if one conforms dramaturgically to certain prevailing cultural prescriptions and proscriptions about what constitutes legitimate science. The case of Parsons clearly violates these assumptions, that is, if we are to take seriously Gouldner's own pronouncements about Parsons and his life's work which he offered near the end of his life. 


\section{Conclusion}

To put all this in perspective, we must note that when Gouldner slipped off this mortal coil back on December 15, 1980 (he was in Spain on a European speaking tour), he did so rather quietly. There were no brass bands playing and little fanfare in celebration of his memory shortly after his passing. He had alienated and offended far too many persons during his lifetime for that. Although he accomplished much during his life-far more than the average social scientist-he also left behind a great deal of unfinished work. But throughout his sixty years, from his childhood as a street-tough kid growing up in Harlem to the towering intellect and scholar he became as an adult, Gouldner was a battler, a conquistador. He gave sociology as well as his life his all. For his sheer tenacity and gritty determination; for believing in something enough to fight and even die for; for trying to make a difference in the world, even though he ultimately failed the biggest tests of substance and character-for all these reasons and more, I join Nord (1992) in viewing Gouldner as an intellectual, if indeed flawed or tragic, hero.

In his hermeneutical study of the writings of Sigmund Freud, Paul Ricoeur (1970, p. 472) argued for a convergence between Hegel's dialectic and Freud's guiding ideas, stating that:

It is always life operations that mark off the dialectic: to risk one's life, to exchange it-to attain satisfaction, to work. It is always the moment of nature, the otherness of life, that, in the proper sense of the word, fosters and nourishes the oppositions of each consciousness to the other than itself.

This sentiment happens to reflect the guiding motif of Gouldner's life and work as well. In Enter Plato, Gouldner put aside space in the preface to describe the trepidation he felt as a sociologist venturing into the world of ancient Greek philosophy. There he (1965, p. vii) wrote that:
It is bad enough when a man has to put his skills up for inspection, but writing becomes a form of prayer when what he places on the line is himself. Yet not all prayers can be granted, and perhaps some are never heard. There is no avoiding this hazard, and, at any rate, this is the only way that I have learned: I have never believed that anything is worth working on unless I seriously risk compromising myself in doing it.

For Gouldner, then, writing was not merely a technical exercise or simply a way of earning a living. Writing revealed an intimate habit of mind, a way of life, an orientation to the world (and beyond). All of the pursuits that mark the life of the scholar-writing, debating, advising students, lecturing, researching, as well as the endless rounds of administrative and committee work-represent in total the risking of a life for those committed to the role of critic. As a result, scholarly work is the embodiment of one's heart and soul and everything the critic stands for intellectually, socially, politically, psychologically. Gouldner's tenacious, even heroic commitment to intellectual matters, and his belief that such matters are consequential and that critical scholars can change the world through their work (for good or evil), are, I contend, good enough reasons for studying and even admiring Alvin Gouldner.

\section{References}

Alt, John. 1981. “Alvin W. Gouldner (1920-1980)." Telos 47:198-203.

Antonio, Robert J. 1995. "Nietzsche's Antisociology: Subjectified Culture and the End of History." American Journal of Sociology 101 (1):1-43.

Argyris, Chris and Donald A. Schon. 1974. Theory in Practice: Increasing Professional Effectiveness. San Francisco: Jossey-Bass.

Aya, Rod. 1982. "The Theory Behind Theory and Society." Theory and Society 11 (6):907-913.

Burawoy, Michael. 1982. "The Written and the Repressed in Gouldner's Industrial Sociology." Theory and Society 11 (6):831-851.

Chriss, James J. 1995a. "Habermas, Goffman, and Communicative Action: Implications for Professional Practice." American Sociological Review 60:545-565. 
Chriss, James J. 1995b. “Testing Gouldner's Coming Crisis Thesis: On the Waxing and Waning of Intellectual Influence." Pp. 33-61 in Current Perspectives in Social Theory, volume 15, edited by B. Agger. Greenwich, CT: JAI Press.

Chriss, James J. 1999a. Alvin W. Gouldner: Sociologist and Outlan Marxist. London: Ashgate.

Chriss, James J. (ed.) 1999b. Counseling and the Therapeutic State. New York: Aldine de Gruyter.

Colvard, Richard. 1990. "Gouldner is Always Worth Reading," American Sociologist 20 (4):381-384.

Coser, Lewis A. 1982. "Remembering Gouldner: Battler, Conquistador, and Free Intelligence." Theory and Society 11 (6):885-888.

Featherstone, Mike. 1995. Undoing Culture: Globalization, Postmodernism and Identity. London: Sage.

Flacks, Richard. 1990. "Gouldner's Prophetic Voice." American Sociologist 20 (4):353-356.

Fuhrman, Ellsworth R. 1990. "Reflexivity and Alvin Gouldner: The Coming Crisis in 1990." American Sociologist 20 (4):357-361.

Glicksberg, Charles I. 1963. The Tragic Vision in Twentieth-Century Literature. Carbondale, IL: Southern Illinois University Press.

Goffman, Erving. 1959. The Presentation of Self in Everyday Life. Garden City, NY: Doubleday Anchor.

Gouldner, Alvin W. 1954a. Patterns of Industrial Bureaucracy. Glencoe: Free Press.

Gouldner, Alvin W. 1954b. Wildcat Strike. Yellow Springs, OH: Antioch Press.

Gouldner, Alvin W. 1956. "Explorations in Applied Social Science." Social Problems 3 (3):169-181.

Gouldner, Alvin W. 1957. "Theoretical Requirements of the Applied Social Sciences." American Sociological Revien 22 (1):92-102.

Gouldner, Alvin W. 1960. "The Norm of Reciprocity: A Preliminary Statement." American Sociological Review 25 (2):161-178.

Gouldner, Alvin W. 1962. "Anti-Minotaur: The Myth of a Value-Free Sociology." Social Problems 9 (3):199-213.

Gouldner, Alvin W. 1965. Enter Plato: Classical Greece and the Origins of Social Theory. New York: Basic Books.

Gouldner, Alvin W. 1968. "The Sociologist as Partisan: Sociology and the Welfare State." American Sociologist 3 (2):103-116.

Gouldner, Alvin W. 1969. "Personal Reality, Social Theory, and the Tragic Dimension in Science." Pp. xvii-xxxviii in The Sociology of Research, G. Boalt. Carbondale: Southern Illinois University Press.

Gouldner, Alvin W. 1970. The Coming Crisis of Western Sociology. New York: Avon.

Gouldner, Alvin W. 1972. "The Politics of the Mind." Social Policy 2 (6):5, 1321, 54-58.
Gouldner, Alvin W. 1973. For Sociology: Renewal and Critique in Sociology Today. New York: Basic Books.

Gouldner, Alvin W. 1975. "Sociology and the Everyday Life." Pp. 417-432 in The Idea of Social Structure, edited by L.A. Coser. New York: Harcourt Brace Jovanovich.

Gouldner, Alvin W. 1975-76. "Prologue to a Theory of Revolutionary Intellectuals." Telos 26:3-36.

Gouldner, Alvin W. 1976a. The Dialectic of Ideology and Technology. New York: Oxford University Press.

Gouldner, Alvin W. 1976b. "The Dark Side of the Dialectic: Toward a New Objectivity." Sociological Inquiry 46 (1):3-15.

Gouldner, Alvin W. 1979a. The Future of Intellectuals and the Rise of the New Class. New York: Seabury Press. Gouldner, Alvin W. 1979b. "Talcott Parsons, 1902-1979." Theory and Society
8:299-302.

Gouldner, Alvin W. 1980. The Two Marxisms. New York: Oxford University Press.

Gouldner, Alvin W. and Richard A. Peterson. 1962. Notes on Tecbnology and the Moral Order. Indianapolis: Bobbs-Merrill.

Habermas, Jurgen. 1984. Theory of Communicative Action, volume one, translated by T. McCarthy. Boston: Beacon Press.

Habermas, Jurgen. 1987. Theory of Communicative Action, volume two, translated by T. McCarthy. Boston: Beacon Press.

Hagan, Robert A. and Ted R. Vaughan. 1990. "The Legacy of The Coming Crisis: Gouldner's Contribution to Social Theory." American Sociologist 20 (4):373-376.

Johnson, Miriam M. 1990. "Gouldner Twenty Years Later." American Sociologist 20 (4):377-380.

Kaplan, Leo S. 1971. "Looking Backward." Transaction 8 (11):6470.

Klausner, Samuel Z. and Victor M. Lidz (eds.) 1986. The Nationalization of the Social Sciences. Philadelphia: University of Pennsylvania Press.

Kuhn, Thomas'S. 1970. The Structure of Scientific Revolutions, $2^{\text {nd }}$ edition. Chicago: University of Chicago Press.

Levesque-Lopman, Louise. 1990. "Seeing Our Seeing: Gouldner's Reflexive Sociology from a Feminist Phenomenological Perspective." American Sociologist 20 (4):362-372.

Miller, S.M. 1981. "Alvin W. Gouldner: The Sociologist as Outlaw Marxist." Social Policy 12 (1):2-6.

Mills, C. Wright. 1959. The Sociological Imagination. London: Oxford University Press.

Nietzsche, Friedrich. 1956. The Birth of Tragedy, translated by F. Golffing. New York: Doubleday.

Nord, Walter R. 1992. "Alvin W. Gouldner as Intellectual Hero." Journal of Management Inquiry 1 (4):350-355. 
Page, Charles H. 1982. Fifty Years in the Sociological Enterprise: A Lucky Journey. Amherst: University of Massachusetts Press.

Pavlich, George. 1995. "Contemplating a Postmodern Sociology: Genealogy, Limits and Critique." Sociological Revien 43 (4):548-572.

Phillips, Bernard S. 1988. "Toward a Reflexive Sociology." American Sociologist 19 (2): Ricoeur, Paul. 1970. Freud and Philosophy, translated by D. Savage. New Haven: Yale University Press.

Stein, Maurice R. 1982. "The Dialectics of Marxism and Sociology During the Buffalo Years." Theory and Society 11 (6):889-897.

Turner, Stephen P. and Jonathan H. Turner. 1990. The Impossible Science: An Institutional Analysis of American Sociology. Newbury Park, CA: Sage.

Weber, Max. 1947. The Theory of Social and Economic Organization, translated by A.M. Henderson and T. Parsons. New York: Free Press.

Weber, Max. 1963. "Soteriology and Types of Salvation." Pp. 184-206 in The Sociology of Religion, M. Weber, translated by E. Fischoff. Boston: Beacon Press.

Young, T.R. 1971. "The Politics of Sociology: Gouldner, Goffman, and Garfinkel.” American Sociologist 6 (4):276-281.

\section{Notes}

'This description of Parsons is deeply ironic, for earlier Gouldner (1969) had argued that in order for sociologists to escape the tragic fate of subordinating themselves to the dictates of the sterile Apollonianism of positivistic social science, sociologists must know themselves (through self-reflection, presumably) so that they can "recognize the value of their human contribution as sufficient to justify their lives." As Gouldner (1969, p. xxxvii) continues, "When great men can do this they will no longer need tacitly to project an inflated image of themselves as gods." So Parsons avoided this tragic fate by "using himself up" in his relentless quest to bring theoretical unity to sociology and the social sciences via structural-functionalism and the AGIL schema. It appears, then, that in 1979, the year Gouldner wrote this eulogy for Parsons, and merely one year before his own death, he had come to the realization that his years of criticizing Parsons had been for naught. This issue will be returned to shortly.

${ }^{2}$ This point requires clarification. Obviously, religion does not simply vanish with the dawning of the age of Enlightenment. Rather, Enlightenment rationalization rationalizes even religion to the point that Christianity is seen by Nietzsche as the prototypical "slave morality" where the earlier promise of earthly salvation gives way to a new range of creeds (e.g., utilitarianism, socialism, evolutionism) that simply secularize and pluralize slave morality, thereby acting as an even more systematic and diffuse mechanism of social control (An- tonio 1995 , p. 8). Another example of this rationalization of religion is the fact that the ancient Greeks were polytheistic, but later civilizations moved toward monotheism, the latter of which Weber (1963) judged to be a more "rationalized" form of religious belief. Nietzsche also believed than in the modern era, genuine Christian conviction had been largely replaced by the new slave moralities, and that faith in God was no longer sincere. Additionally, Nietzsche was critical of the self-delusion of positivists who believed that science could actually replace religion (Antonio 1995, p. 11). Finally, Nietzsche did not view modern society as totally bereft of ultimate values, however, the only genuine values remaining from which to draw meaning were aesthetic values.

3 As Gouldner and Peterson (1962, p. 51) explain, "There is in Apollonianism a development of norm-sending institutions such as ceremonial or ritual and of codified laws, as well as of groups and roles such as a powerful chieftainship, authoritative judges, a restricted council, and an organized priesthood bulwarked by beliefs in the attractiveness of the afterlife."

${ }^{4}$ Kaplan $(1971$, p. 69) goes on to argue that "Gouldner is a Greek. He contributes the golden mean and provides a model that gives a degree of autonomy to man and integrates all the single-factors, weighing each according to the degree of its influence." This is in reference to Gouldner's attempt to overcome the single-factor theories of both functionalism and Marxism through his program of reflexivity and synthesis. Kaplan is invoking the ideal of the Greek program of reflexivity and synthe seen, Gouldner held in such high esteem but which he rarely attained in his personal life. 